\title{
Botanical authentication of lavender (Lavandula spp.) honey by a novel DNA-barcoding approach coupled to high resolution melting analysis
}

\author{
Sónia Soares ${ }^{\mathrm{a}, 1}$, Liliana Grazina ${ }^{\mathrm{a}, 1}$, Joana Costa ${ }^{\mathrm{a}}$, Joana S. Amaral a, b, **, \\ Maria B.P.P. Oliveira ${ }^{a}$, Isabel Mafra ${ }^{\text {a, * }}$ \\ ${ }^{a}$ REQUIMTE-LAQV, Faculdade de Farmácia, Universidade do Porto, Rua de Jorge Viterbo Ferreira, 228, 4050-313 Porto, Portugal \\ ${ }^{\mathrm{b}}$ Instituto Politécnico de Bragança, Campus de Sta. Apolónia, 5301-857 Bragança, Portugal
}

\section{A R T I C L E I N F O}

Article history:

Received 20 October 2017

Received in revised form

29 November 2017

Accepted 30 November 2017

Available online 5 December 2017

\section{Keywords:}

Lavender honey

Authenticity

matK gene

HRM analysis

Lavandula species

Species differentiation

\begin{abstract}
A B S T R A C T
Monofloral honeys (such as, lavender honey) are highly appreciated by the consumers due to their flavour, taste and properties. However, since they are considered prime products, they are often targets of adulteration. This work exploits DNA barcoding combined with high resolution melting (HRM) analysis to establish the botanical origin of honey, using lavender honey as a case study. The plastidial matK gene was targeted as a candidate barcode for Lavandula species identification. The method allowed differentiating the species in three clusters with confidence levels $>99 \%$, being the results well correlated with the sequencing analysis. It was successfully applied to identify the botanical origin of several lavender honeys, which were grouped in the cluster of the most common species in Portugal (L. stoechas subsp., L. penduculata and $L$. viridis). The proposed method represents a simple, specific and cost-effective tool to authenticate the botanical origin of honey.
\end{abstract}

๑) 2017 Elsevier Ltd. All rights reserved.

\section{Introduction}

According to its botanical origin, honey can be classified as mono- or multifloral. The former arises predominantly from one single botanical origin, generally one plant species representing more than $45 \%$ of the total pollen content. Multifloral honeys are composed of pollen grains from several plant species, from which none is considered predominant. Nevertheless, this classification is highly dependent on the pollen source since honeys having underrepresented pollen grains, such as lavender, citrus and rosmarinus, can also be classified as monofloral with a pollen proportion of 10-20\%. In opposition, honeys containing over-represented pollen grains, such as eucalyptus or chestnut, are designated as monofloral if they have a pollen ratio of $70-90 \%$ of the referred plant species (Pires, Estevinho, Feás, Cantalapiedra, \& Iglesias, 2009). Several types of monofloral honeys can be found in Portugal due to the flora

\footnotetext{
* Corresponding author. REQUIMTE-LAQV, Faculdade de Farmácia, Universidade do Porto, Rua de Jorge Viterbo Ferreira, 228, 4050-313 Porto, Portugal.

** Corresponding author. REQUIMTE-LAQV, Faculdade de Farmácia, Universidade do Porto, Rua de Jorge Viterbo Ferreira, 228, 4050-313 Porto, Portugal.

E-mail addresses: jamaral@ipb.pt (J.S. Amaral), isabel.mafra@ff.up.pt (I. Mafra).

1 The authors contributed equally to the present work.
}

diversity. Chestnut (Castanea sativa), lavender (Lavandula spp.) and heather (Erica spp.) honeys are the most frequently found in Portugal (República Portuguesa, 2016). Lavender is an aromatic and very common Mediterranean flowering plant that belongs to the Lamiaceae family, having several species within the Lavandula genus. In Portugal, different species of Lavandula may be responsible for the origin of monofloral lavender honey, depending on their geographical production area, which are: Lavandula stoechas stoechas, L. stoechas luisieri, L. pedunculata (also known as L. stoechas pedunculata) and L. viridis (FNAP, 2017). However, lavender honey from other Lavandula species can be found in other countries, such as France, where this type of honey may be from L. angustifolia, L. latifolia or hybrids of these two species (Guyot-Declerck, Renson, Bouseta, \& Collin, 2002).

Considering that monofloral honeys are highly appreciated by consumers due to their flavour, taste and properties, and generally attain higher prices than the multifloral, they are very prone to fraudulent practices. Accordingly, the botanical origin is determinant to establish the quality and authenticity of honey (CastroVázquez, Leon-Ruiz, Alañon, Pérez-Coello, \& González-Porto, 2014; Soares, Amaral, Oliveira, \& Mafra, 2017). Melissopalynology is still the method used for this purpose, though being timeconsuming and strongly dependent on the qualification and 
judgment of the analysts. Particularly for lavender honeys that contain under-represented pollen grains of Lavandula spp. (15\%), the melissopalynological classification is a very difficult task. To overcome the referred drawbacks, attempts of using physicochemical parameters and/or chemical markers have been carried out to authenticate lavender honey (Castro-Vázquez et al., 2014; Estevinho, Chambó, Pereira, Carvalho, \& Toledo, 2016). However, their assessment can be influenced by the environmental conditions and beekeeping techniques, which might lead recurrently to unreliable identification of the botanical origin. The recent use of DNA markers for pollen identification in honey has demonstrated their feasibility as alternative tools for its botanical determination (Soares et al., 2017). Species-specific real-time PCR assays with TaqMan $^{\mathrm{TM}}$ probes were successfully developed to detect relevant species in Corsican honey (acacia, broom, citrus, clover, heather, eucalyptus, lavender, linden, oak, olive, rape, rockrose, rosemary, sunflower, and sweet chestnut) (Laube et al., 2010). However, previous sample pre-treatments and the selection/optimisation of DNA extraction from honey are crucial steps for further amplification by polymerase chain reaction (PCR) (Jain, Jesus, Marchioro, \& Araújo, 2013; Lalhmangaihi, Ghatak, Laha, Gurusubramanian, \& Kumar, 2014; Soares, Amaral, Oliveira, \& Mafra, 2015).

In the past years, DNA barcoding is an increasingly used approach for taxonomic identification, being suggested to determine the plant and animal species in honey (Bruni et al., 2015; Prosser \& Hebert, 2017; Schnell, Fraser, Willerslev, \& Gilbert, 2010; Valentini, Miquel, \& Taberlet, 2010). In the case of plant differentiation, several DNA barcode regions, such as the plastidial genes matK, trnL and $r b c L$, and the internal transcriber spacers (ITS1 and ITS2) have already been described (Hollingsworth, Graham, \& Little, 2011). Despite the high potentiality of DNA barcoding for the botanical identification of plant species in honey, all the reported methods depend on sequencing analysis, either using Sanger method or NGS (Bruni et al., 2015; Hawkins et al., 2015; Prosser \& Hebert, 2017; Schnell et al., 2010; Valentini et al., 2010). High resolution melting (HRM) analysis can be regarded as a reliable and cost-effective alternative to exploit DNA barcoding, with demonstrated successful applications in the identification of herbal medicines (Costa et al., 2016; Xanthopoulou et al., 2016), and several other plant and animal species in foods (Druml \& CichnaMarkl, 2014; Madesis, Ganopoulos, Sakaridis, Argiriou, \& Tsaftaris, 2014), without requiring further sequencing. Thus, the present work intends to exploit DNA barcoding combined with HRM analysis as an efficient and simple approach to identify the botanical origin of honey. For this purpose, lavender honey was chosen as a case study to differentiate the origin of pollen grains in honey.

\section{Materials and methods}

\subsection{Sample preparation}

Plant material (leaves and seeds) of 9 different voucher species of Lavandula, namely L. stoechas stoechas (two specimens), and L. S. luisieri, L. S. pedundulata, L. pedunculata, L. angustifolia, L. latifolia, $L$. pinnata, $L$. multifida and $L$. viridis (one specimen each), were kindly granted by the Jardim Botânico da Madeira (Funchal, Portugal), Jardim da Fundação de Serralves (Porto, Portugal), Jardim Botânico da UTAD (Vila-Real, Portugal), Real Jardín Botánico Juan Carlos I (Madrid, Spain), Jardin Botanique Strasbourg (Strasbourg, France), Banco de Germoplasma Vegetal Andaluz (Villaviciosa, Córdoba, Spain) and Conservatoire Botanique National de Corse (Corte, Haute-Corse, France). Additionally, one sample of wild and unknown lavender species was collected in the region of Coimbra, centre of Portugal. A detailed description of the selected lavender species is presented in Table 1 . A set of plant species $(n=51)$, frequently identified in the pollen analysis of Portuguese honeys, were used in this work for specificity assays (see sample description in Table S1, supplementary material).

After received, all plant leaves were dried, crushed and stored at room temperature (under desiccation), until DNA extraction. The seeds were crushed and stored at $-20^{\circ} \mathrm{C}$, until DNA extraction.

Commercial honey samples from distinct Portuguese regions ( $n=20)$ were acquired directly from national producers or at local retail markets. A description of each honey is presented in Table 2. Prior to DNA extraction, the honey samples were pre-treated to discard possible interferences for further analysis (Soares et al., 2015). Briefly, $50 \mathrm{~g}$ (4 tubes with $12.5 \mathrm{~g}$ each) of each honey sample were frozen $\left(-80^{\circ} \mathrm{C}\right)$ overnight. After adding distilled water to each tube until a volume of $45 \mathrm{~mL}$, the mixture was vigorously homogenised in vortex and heated at $45^{\circ} \mathrm{C}$ for $5 \mathrm{~min}$. The tubes were centrifuged at $5500 \times \mathrm{g}$ for $20 \mathrm{~min}\left(4^{\circ} \mathrm{C}\right)$ and the supernatant was discarded. The pellet was suspended in $1 \mathrm{~mL}$ of distilled water and further transferred to $2 \mathrm{~mL}$ reaction tubes. The 4 reaction tubes were frozen $\left(-20^{\circ} \mathrm{C}\right)$ overnight, heated at $45^{\circ} \mathrm{C}$ for $5 \mathrm{~min}$ and centrifuged $\left(17,000 \times \mathrm{g}\right.$ for $\left.10 \mathrm{~min}, 4^{\circ} \mathrm{C}\right)$. Again, the pellets were suspended in distilled water and combined in one reaction tube ( $2 \mathrm{~mL}$ ), which was centrifuged $\left(17,000 \times \mathrm{g}\right.$ for $\left.10 \mathrm{~min}, 4^{\circ} \mathrm{C}\right)$. The supernatant was discarded and the pellet was stored at $-20^{\circ} \mathrm{C}$ until DNA extraction.

\subsection{DNA extraction}

DNA from plant species and honey samples was extracted with the commercial kit NucleoSpin ${ }^{\circledR}$ Plant II (Macherey-Nagel, Düren, Germany), according to the manufacture instructions with some minor modifications, as described by Soares et al. (2015). All the DNA extracts were kept at $-20{ }^{\circ} \mathrm{C}$ until further analysis. The extractions were done in duplicate assays for each sample.

The concentration and purity of the extracts were assessed by UV spectrophotometry, using a Synergy HT multi-mode microplate reader with a Take3 micro-volume plate accessory (BioTek Instruments, Inc., Vermont, USA). DNA content was determined using the nucleic acid quantification protocol with sample type defined for double-strand DNA in the Gen5 data analysis software version 2.01 (BioTek Instruments, Inc., Vermont, USA).

The quality of the extracted DNA was further evaluated by electrophoresis in a 1.0\% agarose gel containing Gel Red 1x (Biotium, Hayward, CA, USA) for staining and carried out in SGTB $1 \mathrm{x}$ (GRiSP, Research Solutions, Porto, Portugal) for $20 \mathrm{~min}$ at $200 \mathrm{~V}$. The agarose gel was visualised under a UV light tray Gel Doc ${ }^{\mathrm{TM}}$ EZ System and a digital image was obtained with Image Lab software version 5.1 (Bio-Rad Laboratories, Hercules, CA, USA).

\subsection{Selection of the target gene and oligonucleotide primers}

A DNA sequence of the gene encoding for the plastidial matK of L. stoechas luisieri was retrieved from the NCBI database (http:// www.ncbi.nlm.nih.gov/) (accession number KJ196360.1). Primers Lav1-F (AAA GCT TCT TCC GCT TTG CG) and Lav1-R (TCG TCT TTT TAC CTC TTC ATC CA) were designed to produce DNA fragments of 154 bp with Lavandula species, using the software Primer-BLAST designing tool (http://www.ncbi.nlm.nih.gov/tools/primer-blast/). The nucleotide sequences were submitted to a basic local alignment search tool BLAST (http://blast.ncbi.nlm.nih.gov/Blast.cgi) to identify similar regions of homologue sequences of Lavandula spp. and calculate the statistical significance of the matches. Primer specificity was assessed using the Primer-BLAST tool, which allows revealing homologies in relation to all sequences available in the database (Genbank). Primer properties and the absence of hairpins and self-hybridisation were assessed using the software OligoCalc 
Table 1

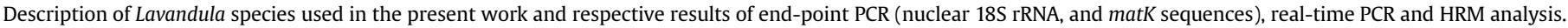

\begin{tabular}{|c|c|c|c|c|c|c|c|c|c|}
\hline \multirow[t]{2}{*}{$\begin{array}{l}\text { Plant } \\
\text { material }\end{array}$} & \multirow[t]{2}{*}{ Species } & \multirow[t]{2}{*}{ Origin } & \multirow[t]{2}{*}{$\begin{array}{l}\text { Accession number/ } \\
\text { Reference }^{\mathrm{a}}\end{array}$} & \multicolumn{2}{|c|}{$\begin{array}{l}\text { End-Point } \\
\text { PCR }^{\mathrm{b}}\end{array}$} & \multicolumn{2}{|c|}{ Real-time PCR } & \multicolumn{2}{|c|}{ HRM analysis } \\
\hline & & & & $\begin{array}{l}18 \mathrm{~S} \\
\text { rRNA }\end{array}$ & matK & $\mathrm{Ct}$ values & $\begin{array}{l}\text { Melting } \\
\text { temperature }\left({ }^{\circ} \mathrm{C}\right)\end{array}$ & Cluster & $\begin{array}{l}\text { Level of } \\
\text { confidence }(\%)^{c}\end{array}$ \\
\hline Leaves & Lavandula spp. & Wild, Coimbra, Portugal & NA & + & + & $20.46 \pm 0.02$ & $76.2 \pm 0.0$ & 1 & $99.1 \pm 0.0$ \\
\hline Seeds & $\begin{array}{l}\text { L. stoechas } \\
\text { luisieri }\end{array}$ & $\begin{array}{l}\text { Banco de Germoplasma Vegetal Andaluz, } \\
\text { Villaviciosa, Córdoba, Spain }\end{array}$ & 14105 & + & + & $18.25 \pm 0.05$ & $76.2 \pm 0.0$ & 1 & $99.7 \pm 0.1$ \\
\hline Seeds & $\begin{array}{l}\text { L. stoechas } \\
\text { stoechas }\end{array}$ & $\begin{array}{l}\text { Conservatoire Botanique National de Corse, } \\
\text { Canavaggia, Haute-Corse, France }\end{array}$ & NP & + & + & $18.51 \pm 0.03$ & $76.2 \pm 0.0$ & 1 & $99.9 \pm 0.0$ \\
\hline Leaves & $\begin{array}{l}\text { L. stoechas } \\
\text { stoechas }\end{array}$ & $\begin{array}{l}\text { Conservatoire Botanique National de Corse, Corte, } \\
\text { Haute-Corse, France }\end{array}$ & NP & + & + & $21.12 \pm 0.04$ & $76.2 \pm 0.0$ & 1 & $99.9 \pm 0.0$ \\
\hline Seeds & $\begin{array}{l}\text { L. stoechas } \\
\text { pedunculata }\end{array}$ & $\begin{array}{l}\text { Banco de Germoplasma Vegetal Andaluz, Trassierra, } \\
\text { Córdoba, Spain }\end{array}$ & 15304 & + & + & $18.55 \pm 0.05$ & $76.2 \pm 0.0$ & 1 & $100.0 \pm 0.0$ \\
\hline Leaves & L. penduculata & Jardim Botânico da Madeira, Funchal, Portugal & $\begin{array}{l}\text { PT-O-MADJ-33- } \\
2014\end{array}$ & + & + & $20.42 \pm 0.80$ & $76.1 \pm 0.1$ & 1 & $99.8 \pm 0.0$ \\
\hline Seeds & L. viridis & Real Jardín Botánico Juan Carlos I, Madrid, Spain & ALCA-BG-0404/02 & + & + & $17.73 \pm 0.62$ & $76.2 \pm 0.0$ & 1 & $99.7 \pm 0.0$ \\
\hline Seeds & L. pinnata & Jardim Botânico da Madeira, Funchal, Portugal & $\begin{array}{l}\text { PT-O-MADJ-24- } \\
2015\end{array}$ & + & + & $17.67 \pm 0.05$ & $76.8 \pm 0.0$ & 2 & $99.7 \pm 0.1$ \\
\hline Leaves & L. multífida & Jardim da Fundação de Serralves, Porto, Portugal & NP & + & + & $17.02 \pm 0.48$ & $76.6 \pm 0.0$ & 2 & $99.6 \pm 0.1$ \\
\hline Leaves & L. angustifolia & Jardim Botânico da UTAD, Vila Real, Portugal & NP & + & + & $22.27 \pm 0.09$ & $76.6 \pm 0.0$ & 3 & $100.0 \pm 0.0$ \\
\hline Seeds & L. latifolia & Jardin Botanique Strasbourg, Strasbourg, France & $1979 / 359$ & + & + & $24.57 \pm 0.27$ & $76.6 \pm 0.0$ & 3 & $99.9 \pm 0.1$ \\
\hline
\end{tabular}

a NA, not applicable; NP, not provided.

b (+) positive amplification; ( - ) negative amplification.

c Mean values \pm standard deviation of $n=4$ replicates.

Table 2

Description of analysed honey samples and respective results of end-point PCR (nuclear 18S rRNA, and matK sequences), real-time PCR and HRM analysis.

\begin{tabular}{|c|c|c|c|c|c|c|c|c|}
\hline \multirow[t]{2}{*}{ Honey } & \multirow[t]{2}{*}{ Botanical origin } & \multirow[t]{2}{*}{ Geographical origin } & \multicolumn{2}{|c|}{ End-point $\mathrm{PCR}^{\mathrm{a}}$} & \multicolumn{2}{|c|}{ Real-time $\mathrm{PCR}^{\mathrm{b}}$} & \multicolumn{2}{|c|}{ HRM analysis } \\
\hline & & & 18S rRNA & matK & $\mathrm{Ct}_{\text {values }}^{\mathrm{a}}$ & Melting temperature $\left({ }^{\circ} \mathrm{C}\right)$ & Cluster & Level of confidence (\%) \\
\hline 1 & Lavander & Vila Real, Portugal & + & + & $31.62 \pm 0.23$ & $76.0 \pm 0.0$ & 1 & $99.8 \pm 0.0$ \\
\hline 2 & Lavender + Linden & Castelo Branco, Portugal & + & + & $30.18 \pm 0.12$ & $75.9 \pm 0.1$ & 1 & $99.8 \pm 0.2$ \\
\hline 3 & Lavander & Serra da Malcata, Portugal & + & + & $32.74 \pm 0.24$ & $76.0 \pm 0.0$ & 1 & $99.8 \pm 0.1$ \\
\hline 4 & Lavander & Portugal & + & + & $31.57 \pm 0.02$ & $76.0 \pm 0.0$ & 1 & $99.8 \pm 0.1$ \\
\hline 5 & Lavander & Alto Tâmega, Portugal & + & + & $33.21 \pm 0.19$ & $76.0 \pm 0.0$ & 1 & $99.9 \pm 0.1$ \\
\hline 6 & Lavander & Portugal & + & + & $30.13 \pm 0.10$ & $75.9 \pm 0.1$ & 1 & $99.6 \pm 0.2$ \\
\hline 7 & Lavander & Serra de Portel, Portugal & + & + & $32.05 \pm 0.23$ & $76.2 \pm 0.0$ & 1 & $99.7 \pm 0.2$ \\
\hline 8 & Lavander & Serra de Portel, Portugal & + & + & $30.69 \pm 0.14$ & $76.0 \pm 0.0$ & 1 & $99.6 \pm 0.1$ \\
\hline 9 & Lavander & Mértola, Portugal & + & + & $29.26 \pm 0.08$ & $76.0 \pm 0.0$ & 1 & $99.8 \pm 0.2$ \\
\hline 10 & Lavander & Mértola, Portugal & + & + & $29.89 \pm 0.21$ & $75.9 \pm 0.0$ & 1 & $99.7 \pm 0.1$ \\
\hline 11 & Lavender + Almond & Douro, Portugal & + & \pm & - & & & \\
\hline 12 & Lavander & Amarante, Portugal & + & + & $31.32 \pm 0.14$ & $76.0 \pm 0.0$ & 1 & $99.9 \pm 0.0$ \\
\hline 13 & Lavander & Batalha, Portugal & + & + & $32.23 \pm 0.12$ & $76.3 \pm 0.2$ & 1 & $99.3 \pm 0.2$ \\
\hline 14 & Lavander & Vila Real, Portugal & + & + & $32.54 \pm 0.10$ & $76.0 \pm 0.0$ & 1 & $99.8 \pm 0.1$ \\
\hline 15 & Lavander & Algarve, Portugal & + & + & $32.15 \pm 0.09$ & $76.2 \pm 0.0$ & 1 & $99.7 \pm 0.2$ \\
\hline 16 & Lavender & Palmela, Portugal & + & \pm & - & & & \\
\hline 17 & Multifloral & Montesinho, Bragança & + & - & NA & & & \\
\hline 18 & Multifloral & Trás-os-montes, Portugal & + & - & NA & & & \\
\hline 19 & Lavender & Aljezur, Portugal & + & \pm & - & & & \\
\hline 20 & Lavender & Zavial, Algarve, Portugal & + & \pm & - & & & \\
\hline
\end{tabular}

a $(+)$ positive amplification; ( - ) negative amplification.

b Mean values \pm standard deviation of $n=4$ replicates; NA - not applicable.

(http://www.basic.northwestern.edu./bio-tools/oligocalc.html). The designed primers were synthesised by STABVIDA (Lisbon, Portugal).

\subsection{End-point PCR}

The PCR amplifications were carried out in a total reaction volume of $25 \mu \mathrm{L}$, containing $2 \mu \mathrm{L}$ of DNA extract ( $<20 \mathrm{ng}$ ), $67 \mathrm{mM}$ Tris- $\mathrm{HCl}$ (pH 8.8), $16 \mathrm{mM}$ of $\left(\mathrm{NH}_{4}\right)_{2} \mathrm{SO}_{4}, 0.1 \%$ of Tween $20,200 \mu \mathrm{M}$ of each dNTP, $1.0 \mathrm{U}$ of SuperHot Taq DNA Polymerase (Genaxxon Bioscience $\mathrm{GmbH}$, Ulm, Germany), $3.0 \mathrm{mM}$ of $\mathrm{MgCl}_{2}$, and $200 \mathrm{nM}$ of each primer Lav1-F and Lav1-R. The reactions were performed in a thermal cycler MJ MiniтM Gradient Thermal Cycler (Bio-Rad Laboratories, Hercules, CA, USA) using the following program: (i) initial denaturation at $95^{\circ} \mathrm{C}$ for $5 \mathrm{~min}$; (ii) 40 cycles at $95^{\circ} \mathrm{C}$ for $30 \mathrm{~s}, 55^{\circ} \mathrm{C}$ for $30 \mathrm{~s}$ and $72{ }^{\circ} \mathrm{C}$ for $30 \mathrm{~s}$; (iii) and a final extension at $72{ }^{\circ} \mathrm{C}$ for 5 min.

The amplified fragments were analysed by electrophoresis in a $1.5 \%$ agarose gel containing Gel Red $1 x$ (Biotium, Hayward, CA, USA) for staining and carried out in SGTB 1x (GRiSP, Research Solutions, Porto, Portugal). The agarose gel was visualised under a UV light tray Gel Doc ${ }^{\mathrm{TM}}$ EZ System and a digital image was obtained with Image Lab software version 5.1 (Bio-Rad Laboratories, Hercules, CA, USA). Each extract was amplified at least in duplicate assays.

\subsection{Real-time PCR and HRM analysis}

The real-time PCR assays were performed in $20 \mu \mathrm{L}$ of total reaction volume, containing $2 \mu \mathrm{L}$ of DNA extract $(<20 \mathrm{ng}), 1 \times$ of SsoFast ${ }^{\mathrm{TM}}$ EvaGreen ${ }^{\circledR}$ Supermix (Bio-Rad Laboratories, Hercules, CA, 
USA), $400 \mathrm{nM}$ of each primer Lav1-F/Lav1-R. The assays were carried out on a fluorometric thermal cycler CFX96 Real-time PCR Detection System (Bio-Rad Laboratories, Hercules, CA, USA), according to the following temperature programme: $95{ }^{\circ} \mathrm{C}$ for $5 \mathrm{~min}$, 50 cycles at $95{ }^{\circ} \mathrm{C}$ for $15 \mathrm{~s}, 55^{\circ} \mathrm{C}$ for $15 \mathrm{~s}$ and $72{ }^{\circ} \mathrm{C}$ for $25 \mathrm{~s}$, with the collection of fluorescence signal at the end of each cycle. Data were collected and processed using the software Bio-Rad CFX Manager 3.1 (Bio-Rad Laboratories, Hercules, CA, USA). Real-time PCR trials were repeated in two independent assays using four replicates in each one.

For HRM analysis, PCR products were denatured at $95{ }^{\circ} \mathrm{C}$ for $1 \mathrm{~min}$ and then annealed at $60{ }^{\circ} \mathrm{C}$ for $5 \mathrm{~min}$ in order to allow the correct annealing of the DNA duplexes. These two steps were followed by melting curve ranging from 60 to $90^{\circ} \mathrm{C}$ with temperature increments of $0.2{ }^{\circ} \mathrm{C}$ every $10 \mathrm{~s}$. The fluorescence data were acquired at the end of each melting temperature, which were processed using the Precision Melt Analysis Software 1.2 (Bio-Rad Laboratories, Hercules, CA, USA) to generate melting curves as a function of temperature and difference curves for easier visual identification of clusters. Cluster detection settings were defined targeting high sensitivity and threshold yields for more heterozygote clusters. Melting curve shape sensitivity parameter was adjusted to percentage value $50 \%$ and $\mathrm{Tm}$ difference threshold parameter was set as a default value of 0.30 .

\subsection{Sequencing of $P C R$ products}

To corroborate the HRM analysis, the PCR products with Lav1-F/ Lav1-R primers of the 11 different specimens of Lavandula were sequenced. After the amplification according to the previously optimised conditions, the PCR products were purified with GRS PCR $\&$ Gel Band Purification Kit (GRISP, Porto, Portugal) to remove any possible interfering components and sent to a specialised research facility (GATC Biotech, Constance, Germany) for sequencing. Each target fragment was sequenced twice, performing the direct sequencing of both strands in opposite directions, which allowed the production of two complementary sequences with very good quality. The sequencing data were analysed using the available software BioEdit v7.2.5 (Ibis Biosciences, Carlsbad, CA, USA) and FinchTV (Geospiza, Seattle, WA, USA).

\section{Results and discussion}

\subsection{Evaluation of extracted DNA}

In general, the lavender DNA extracts exhibited an adequate concentration (3.8-193.4 ng/ $\mu \mathrm{L})$, although low values were obtained for some plant materials (particularly the seeds). Similar values of DNA yield were achieved for honey samples, with concentrations ranging from 4.4 to $275.9 \mathrm{ng} / \mu \mathrm{L}$. The reported DNA concentrations are in good agreement with literature. Bruni et al. (2015) attained yields that ranged $10-25 \mathrm{ng} / \mu \mathrm{L}$ using a different extraction kit and an additional purification kit. Generally, DNA yields were also in good accordance with the electrophoretic analysis. For the 11 plant species tested, DNA extracts presented purities ranging from 1.5 to 2.1, while for honey samples the purities ranged from 1.9 to 2.3 .

\subsection{End-point $P C R$}

To evaluate the amplification capacity of the DNA extracts, all samples were tested with primers EG-F/EG-R targeting a universal eukaryotic fragment (Tables 1 and 2), as described by Villa, Costa, Oliveira, and Mafra (2017). All the extracts of the Lavandula voucher specimens and honey samples were successfully amplified, showing strong PCR products with the expected size of $109 \mathrm{bp}$ (data not shown) and confirming the suitability of all DNA extracts for further PCR amplification.

The plastidial matK gene was the selected DNA region for the design of a new pair of primer to differentiate Lavandula species/ subspecies. This choice was related to the fact that matK gene has been proposed as a universal DNA barcode for flowering plants (Lahaye et al., 2008; Selvaraj, Sarma, \& Sathishkumar, 2008). Besides, the combined approach of matK, as a mini-barcode candidate, with HRM analysis was already demonstrated for Crocus spp. differentiation (Villa, Costa, Meira, Oliveira, \& Mafra, 2016). So, the new primers (Lav1-F/Lav1-R) targeting the matK sequence were used to amplify DNA from the voucher specimens under study. As expected, all the tested specimens were amplified, obtaining PCR products of $154 \mathrm{bp}$ (Table 1 ). To experimentally confirm their specificity for Lavandula spp., previously demonstrated by the in silico analysis, other 51 plant species, including those most commonly found in Portuguese honeys, were tested to verify any possible reactivity. The results are presented in Table S1 (supplementary material), showing that 5 plant species, namely Salvia

A
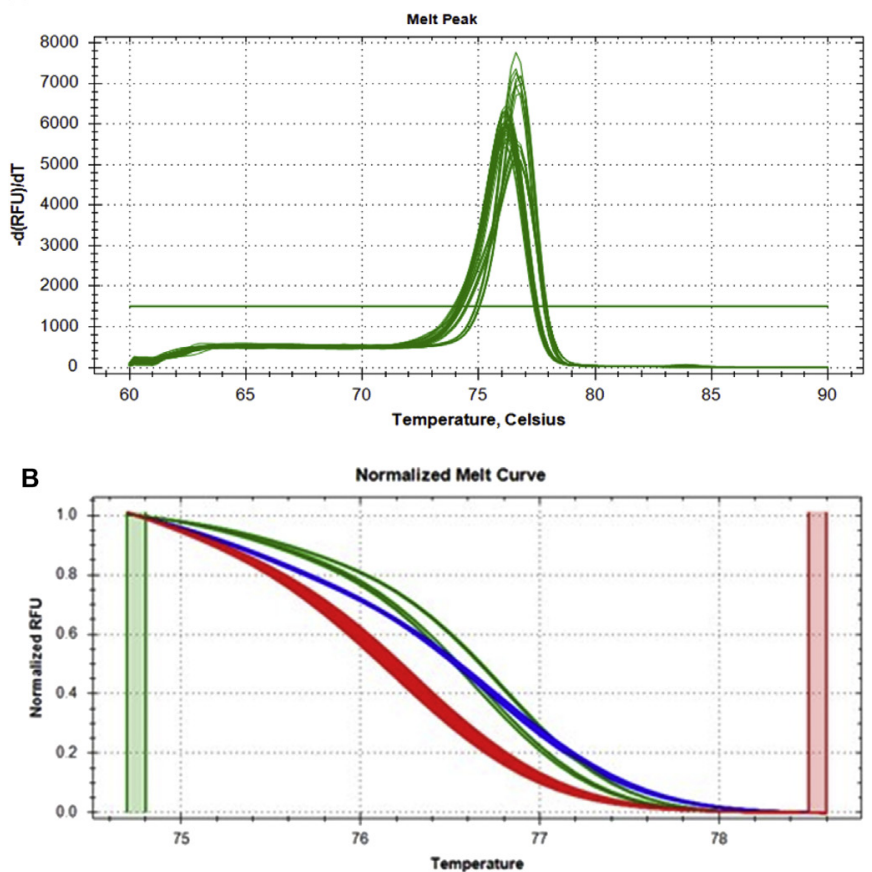

C Diflerences Curve

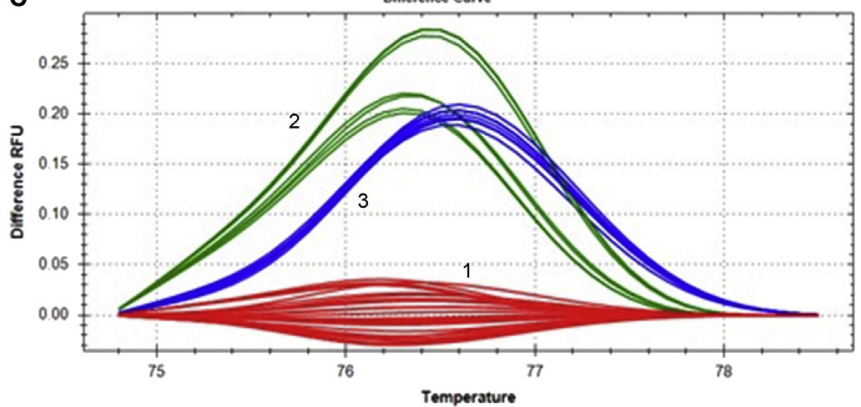

Fig. 1. Conventional melting curves (B), normalised melting curves (C) and difference curves (D) obtained by real-time PCR amplification with EvaGreen dye and HRM analysis targeting the matK gene of Lavandula spp. $(n=4)$. Legend: 1 , wild lavender, L. stoechas luisieri, L. S. stoechas (Canavaggia), L. s. stoechas (Corte), L. s. pedunculata, L. pedunculata, L. viridis; 2, L. pinnata, L. multífida; 3, L. angustifolia, L. latifolia. 
officinalis, Mentha $x$ piperita, Aloysia citrodora (belonging to the Lamiales order, such as the samples of Lavandula spp.), Genista tridentate and Erica australis, were also positive for the expected fragment of $154 \mathrm{bp}$, while the others did not produce any PCR product. From these species, E. australis can be considered a relevant cross-reactivity because Erica spp. are pollen sources for heather honey, very common in Portugal.

The applicability of the Lav1-F/Lav1-R primers to detect different Lavandula spp. in honey was further demonstrated in the analysis of 18 lavender and two multifloral honey samples (Table 2). The obtained results showed fragments of 154 bp for the 18 lavender honey samples, though four of them (\#11, \#16, \#19, \#20) presented weak amplification (faint bands), probably due to low target DNA since the amplification of a universal eukaryotic sequence was obtained with strong fragments (Fig. S1, supplementary material). It is important to refer that lavender honeys have under represented pollen grains of Lavandula spp., which might justify the particularly low amount of target DNA in some samples. The two multifloral honey samples (\#17 and \#18) did not show any PCR fragment, possibly due to the absence or very low proportion of lavender pollen.

\subsection{Real-time PCR with HRM analysis}

Following the encouraging results of end-point PCR targeting the matK gene with Lav1-F/Lav1-R primers, the amplification by real-time PCR with EvaGreen dye was then proceeded using the different Lavandula specimens under study. The real-time PCR results were in good agreement with those previously obtained by end-point PCR since all specimens were amplified with cycle threshold values ranging from 17.02 to 24.57 (Table 1). Fig. 1A shows the melting curves obtained for the assayed species/subspecies, namely $L$. stoechas stoechas, $L$. stoechas luisieri, $L$. stoechas pedundulata, $L$. pedunculata, $L$. angustifolia, $L$. latifolia, $L$. pinnata, $L$. multifida, $L$. viridis and wild lavender. The melting curve analysis revealed peaks with very close melting temperatures (Tm), though three groups can be visualised: (i) at $76.2{ }^{\circ} \mathrm{C}$ for wild lavender, L. stoechas subsp., L. pedunculata and L. viridis; (ii) at $76.6{ }^{\circ} \mathrm{C}$ for L. multifida, L. angustifolia and L. latifolia; (iii) at $76.8^{\circ} \mathrm{C}$ for L. pinnata
(Fig. 1A and Table 1). However, based on the close melting temperatures and similarity of profiles, it is not possible to clearly differentiate them by conventional melting curve analysis.

As an attempt to distinguish all the Lavandula species/subspecies, HRM analysis was applied as a tool with high potentialities to discriminate closely related taxa. The results are displayed as normalised melt and difference curves in Fig. 1B and C, respectively. As it can be seen, the specimens were divided in three distinct clusters with high levels of confidence ( $\geq 99.1 \%$ ). Cluster 1 , nominated as the reference cluster, included the wild lavender, $L$. stoechas subsp., $L$. pedunculata and $L$. viridis, which is a group in good agreement with the results of conventional melting curve analysis, having all practically the same Tm. Cluster 2 comprised the species $L$. pinnata and L. multifida, while cluster 3 included the L. angustifolia and L. latifolia. These findings are in good agreement with the fact that the lavender species, included in cluster 1 , are the most frequent in the Portuguese flora (FNAP, 2017). L. angustifolia and L. latifolia, included in cluster 3, are more common in the French flora (GuyotDeclerck et al., 2002). According to Chograni, Messaoud, and Boussaid (2008), there is a high genetic divergence between L. stoechas and L. multifida populations based on isozymes, which corroborates their distinct taxonomic status and separate cluster classification.

Considering the relevant reactivity of the proposed primers with E. australis, a real-time PCR assay with melting curve analysis and HRM analysis was further performed with this species together with Lavandula spp. representative of each cluster. The results confirmed the amplification of $E$. australis by real-time PCR targeting matk gene, displaying a $\operatorname{Tm}$ of $76.8^{\circ} \mathrm{C}$, very close to the ones of $L$. angustifolia, L. pinnata, but exhibiting a slightly different profile owing to the presence of a "shoulder" before the melt peak (Fig. S2A, supplementary material). However, with the application of HRM analysis those melting profile differences were intensified and $E$. australis was completely discriminated, being separated in a distinct cluster from the other three Lavandula spp. (Figs. S2B and S2C, supplementary material). Accordingly, the HRM assay specificity was further confirmed as suitable to differentiate Lavandula spp.

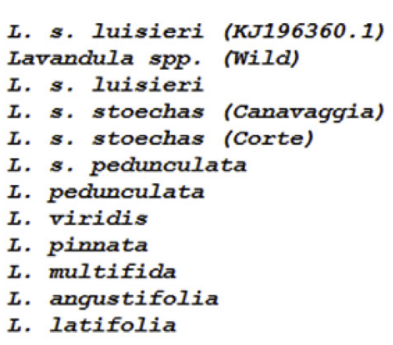

L. s. Luisieri (KJ196360.1)

Lavandula spp. (Wild)

L. s. Iuisieri

L. s. stoechas (Canavaggia)

L. s. stoechas (Corte)

L. s. pedunculata

L. pedunculata

L. viridis

L. pinnata

L. multifida

L. angustifolia

L. latifolia
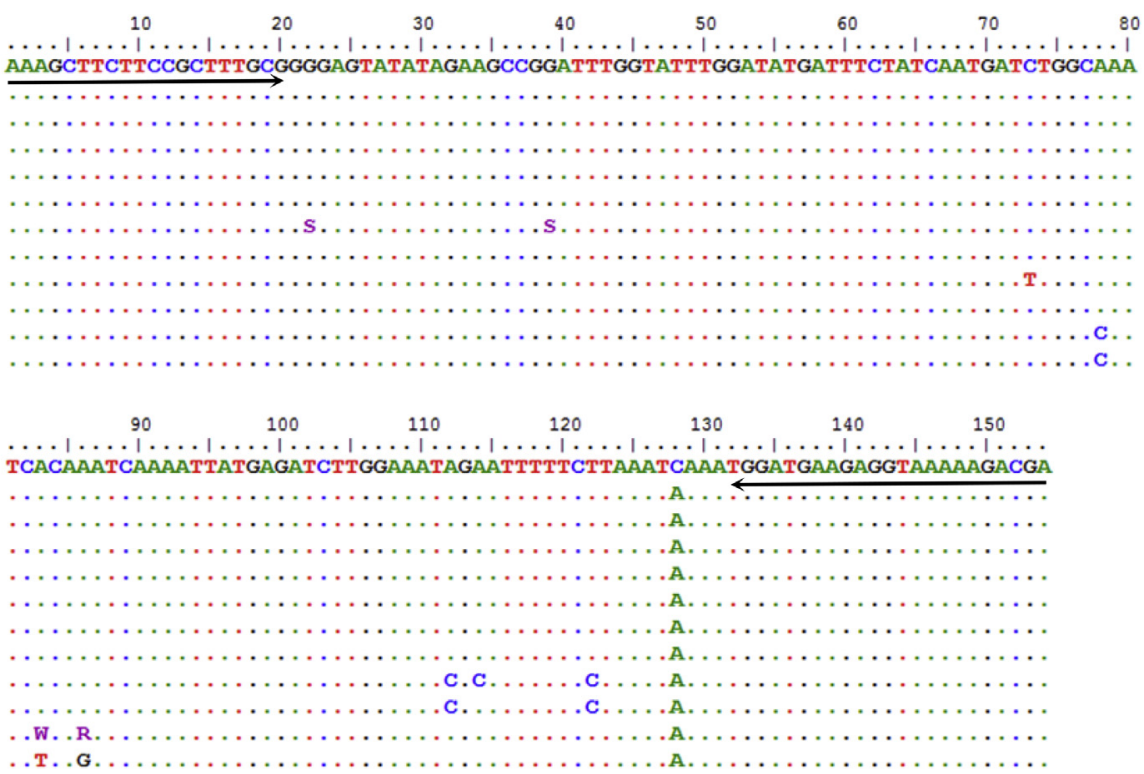

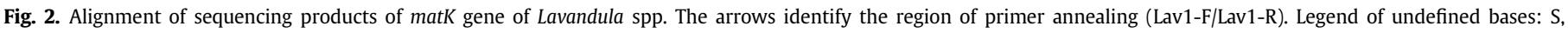
represents $\mathrm{C}$ or $\mathrm{G}$; W, A or T; and R, A or G. 


\subsection{Sequencing results}

To further confirm and validate the results of HRM analysis, the PCR products of the 11 Lavandula specimens amplified with the Lav1-F/Lav1-R primers were sequenced in opposite directions, obtaining electropherograms with high resolution and a total coverage of the $154 \mathrm{bp}$ fragments. The results were aligned with the GenBank retrieved sequence (accession number KJ196360.1) in which the primers were designed and are presented in Fig. 2. Firstly, it can be observed a consistent mismatch $(\mathrm{C} \rightarrow \mathrm{A})$ in the position 128 in all the obtained sequences, which might suggest the misidentification of that base from the consensus sequence (accession number KJ196360.1). Comparing the sequences from the specimens of cluster 1, namely wild Lavandula, L. stoechas luisieri, L. stoechas stoechas (Canavaggia and Corte), L. stoechas pedundulata and $L$. pedunculata, it can be verified that they share the same sequence, except for two nucleotides of $L$. pedunculata not completely identified (S at positions 23 and 39). However, since S can in fact be a $\mathrm{C}$, these sequences might be in full agreement. This finding justifies the inclusion of all these specimens in the same cluster, which is also in good agreement with the fact that L. stoechas stoechas, L. stoechas luisieri, L. pedunculata (also known as L. stoechas pedunculata) and L. viridis are the most common Lavandula species in Portugal (FNAP, 2017), being all genetically close. The specimen of wild lavender is probably one of those species. L. pinnata sequence presented 4 mismatches, while L. multifida showed 2, being two of them in common, namely $\mathrm{A} \rightarrow \mathrm{C}$ and $\mathrm{T} \rightarrow \mathrm{C}$ at the positions 112 and 122, respectively. The other two mismatches of $L$. pinnata sequence are $\mathrm{C} \rightarrow \mathrm{T}$ and $\mathrm{A} \rightarrow \mathrm{C}$ at the positions 73 and 114 , respectively. Therefore, the partial mismatch sharing by these two species corroborates the HRM results, which include them in a distinct cluster. The sequences of $L$. angustifolia and $L$. latifolia share three mismatches in the same positions (78, 83 and 86$)$. The first mismatch $(A \rightarrow C)$ was consistent in both species. The other two mismatches were clearly identified in L. latifolia $(83, \mathrm{~A} \rightarrow \mathrm{T}$ and 86 , $A \rightarrow G)$, but not in L. angustifolia $(83, A \rightarrow W(A$ or $T)$ and $86, A \rightarrow R(A$ or $G)$ ), though they might be also coincident. This agrees with the genetic proximity of both species, commonly designated as French lavenders (Guyot-Declerck et al., 2002), and clearly justifies their inclusion in a distinct HRM cluster.

\subsection{Application of the HRM analysis to honey samples}

After the development and validation of the HRM method, the honey samples that showed the expected PCR fragment with Lav1R/Lav1-F were further amplified by real-time PCR with the same primers. As expected, honey samples \#1 to \#10 and \#12 to \#15 were confirmed as positive for Lavandula spp. by real-time PCR with $\mathrm{Ct}$ values ranging from 29.26 to 33.21 (Table 2). The weak amplification results obtained by qualitative PCR in 4 samples (\#11, \#16, \#19 and \#20) were not confirmed by real-time PCR, suggesting again the low amount of the target DNA. It is important to highlight that despite the main efforts performed in the DNA extraction procedure from honey, including a previous sample pre-treatment, it was difficult to obtain high levels of amplification by real-time PCR. Even though, conventional melting curve and HRM analysis could be successfully applied to all the referred 14 honey samples (\#1-\#10, \#12-\#15). Fig. 3 shows an example assay of the melting curve and HRM analysis applied to 4 of the analysed honey samples together with the Lavandula voucher specimens. The obtained Tm of the 14 honey samples ranged from $75.9^{\circ} \mathrm{C}$ to $76.3^{\circ} \mathrm{C}$ (Fig. $3 \mathrm{~A}$, Table 2), being in the vicinity of the Tm of the Lavandula species frequently found in Portugal. As expected, the HRM analysis confirmed this assumption by placing all the honey samples in the same cluster (cluster 1) of the Portuguese Lavandula species with
A

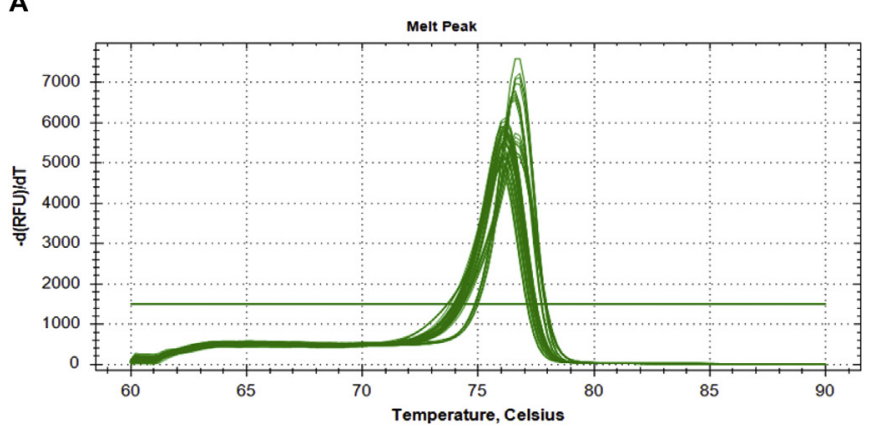

B
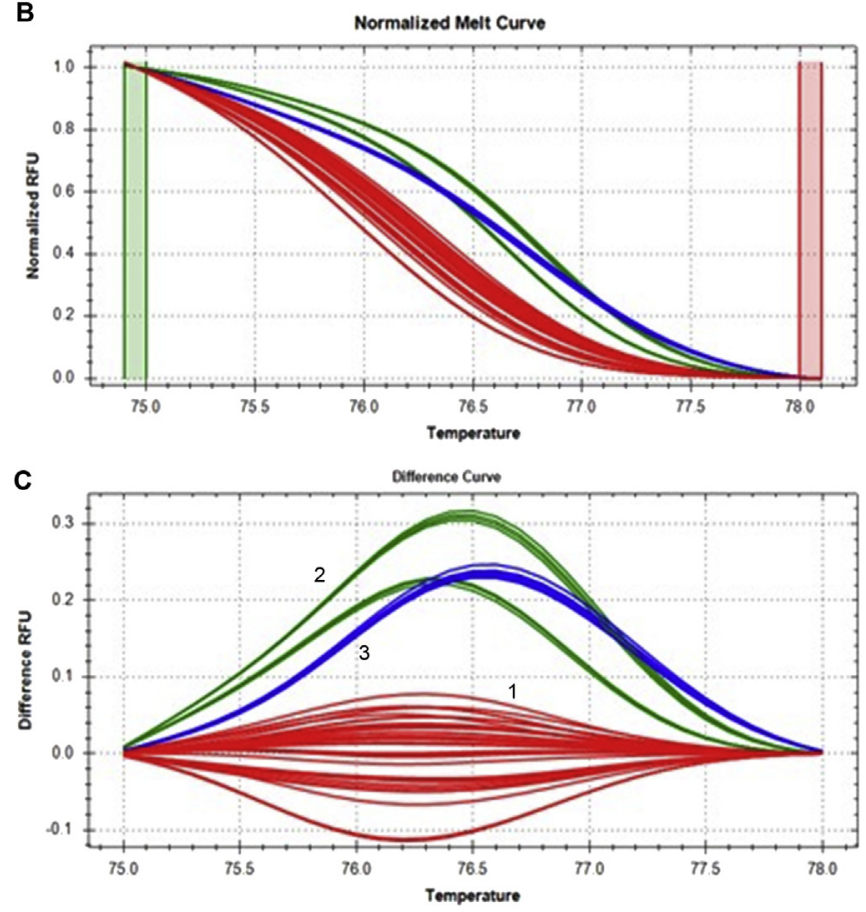

Fig. 3. Conventional melting curves (A), normalised melting curves (B) and difference curves (C) obtained by real-time PCR amplification with EvaGreen dye and HRM analysis targeting the matK gene of Lavandula spp. $(n=4)$. Legend: 1 , wild lavender, L. stoechas luisieri, L. s. stoechas (Canavaggia), L. s. pedunculata, L. pedunculata, L. viridis, honey samples (\#6, \#8, \#12, \#13, see Table 2); 2, L. pinnata, L. multífida; 3, L. angustifolia, L. latifolia.

high level of confidence ( $\geq 99.3 \%$ ) (Fig. 3B and C, Table 2). This demonstrates the feasibility of the proposed HRM method to authenticate the botanical origin of lavender honeys.

\section{Conclusions}

In the present work, we propose a combination of the matK gene, as a DNA barcode suggested for plants, with HRM analysis as a highly specific approach to identify different Lavandula species. The method enabled the differentiation of lavender species in 3 distinct clusters with high level of confidence ( $\geq 99 \%$ ): the lavender species commonly found in Portugal (L. stoechas subsp., L. pedunculata and $L$. viridis); the species $L$. multifida and L. pinnata; and the French lavender species ( $L$. angustifolia and L. latifolia). The HRM results were well correlated with the sequencing data, proving the adequacy of the method to authenticate the botanical origin of honey. Hereby, we present a reliable and fast DNA-based methodology to assess the botanical origin of Portuguese monofloral lavender honey, which can be highlighted as a suitable alternative to the 
currently used melyssopalynological analysis. To our knowledge, this is the first study using DNA barcoding combined with HRM analysis for the simple, cost-effective and rapid discrimination/ identification of plant species in honey.

\section{Acknowledgments}

This work was supported by FCT (Fundação para a Ciência e Tecnologia) through project UID/QUI/50006/2013 - POCI/01/0145/ FEDER/007265 with financial support from FCT/MEC through national funds and co-financed by FEDER, under the Partnership Agreement PT2020 and by the project NORTE-01-0145-FEDER000011. S. Soares, L. Grazina and J. Costa are grateful to FCT grants (SFRH/BD/75091/2010, SFRH/BD/132462/2017 and SFRH/BPD/ 102404/2014, respectively) financed by POPH-QREN (subsidised by FSE and MCTES). The authors are grateful for the kind supply of voucher seeds and leaves from Jardim Botânico da Madeira (Funchal, Portugal), Jardim da Fundação de Serralves (Porto, Portugal), RBG Kew Garden (Kew, United Kingdom), Jardim Botânico da UTAD (Vila Real, Portugal), Real Jardín Botánico Juan Carlos I (Madrid, Spain), Jardin Botanique Strasbourg (Strasbourg, France), Banco de Germoplasma Vegetal Andaluz (Villaviciosa, Spain) and Conservatoire Botanique National de Corse (Haute-Corse, France).

\section{Appendix A. Supplementary data}

Supplementary data related to this article can be found at https://doi.org/10.1016/j.foodcont.2017.11.046.

\section{References}

Bruni, I., Galimberti, A., Caridi, L., Scaccabarozzi, D., De Mattia, F., Casiraghi, M., et al (2015). A DNA barcoding approach to identify plant species in multiflower honey. Food Chemistry, 170(0), 308-315.

Castro-Vázquez, L., Leon-Ruiz, V., Alañon, M. E., Pérez-Coello, M. S., \& GonzálezPorto, A. V. (2014). Floral origin markers for authenticating Lavandin honey (Lavandula angustifolia x latifolia). Discrimination from Lavender honey (Lavandula latifolia). Food Control, 37, 362-370.

Chograni, H., Messaoud, C., \& Boussaid, M. (2008). Genetic diversity and population structure in Tunisian Lavandula stoechas L. and Lavandula multifida L. (Lamiaceae). Biochemical Systematics and Ecology, 36(5), 349-359.

Costa, J., Campos, B., Amaral, J. S., Nunes, M. E., Oliveira, M. B. P. P., \& Mafra, I. (2016). HRM analysis targeting ITS1 and matK loci as potential DNA mini-barcodes for the authentication of Hypericum perforatum and Hypericum androsaemum in herbal infusions. Food Control, 61, 105-114.

Druml, B., \& Cichna-Markl, M. (2014). High resolution melting (HRM) analysis of DNA - its role and potential in food analysis. Food Chemistry, 158, 245-254.

Estevinho, L. M., Chambó, E. D., Pereira, A. P. R., Carvalho, C. A. L., \& Toledo, V. A. A. (2016). Characterization of Lavandula spp. honey using multivariate techniques. PLOS ONE, 11(9), e0162206.
FNAP. (2017). Mel de rosmaninho Português - um alimento funcional e fonte de nutracêuticos. http://fnap.pt/projectos/projecto-mel-de-rosmaninhoportugues/. (Accessed 15 June 2017).

Guyot-Declerck, C., Renson, S., Bouseta, A., \& Collin, S. (2002). Floral quality and discrimination of Lavandula stoechas, Lavandula angustifolia, and Lavandula angustifolia $\times$ latifolia honeys. Food Chemistry, 79(4), 453-459.

Hawkins, J., de Vere, N., Griffith, A., Ford, C. R., Allainguillaume, J., Hegarty, M. J., et al. (2015). Using DNA metabarcoding to identify the floral composition of honey: A new tool for investigating honey bee foraging preferences. PLoS One, 10(8), e0134735.

Hollingsworth, P. M., Graham, S. W., \& Little, D. P. (2011). Choosing and using a plant DNA barcode. PLoS One, 6(5), e19254.

Jain, S. A., Jesus, F. T., Marchioro, G. M., \& Araújo, E. D. (2013). Extraction of DNA from honey and its amplification by PCR for botanical identification. Food Science and Technology, 33, 753-756.

Lahaye, R., van der Bank, M., Bogarin, D., Warner, J., Pupulin, F., Gigot, G., et al. (2008). DNA barcoding the floras of biodiversity hotspots. Proceedings of the National Academy of Sciences, 105(8), 2923-2928.

Lalhmangaihi, R., Ghatak, S., Laha, R., Gurusubramanian, G., \& Kumar, N. S. (2014). Protocol for optimal quality and quantity pollen DNA isolation from honey samples. Journal of Biomolecular Techniques, 25(4), 1-4.

Laube, I., Hird, H., Brodmann, P., Ullmann, S., Schöne-Michling, M., Chisholm, J., et al. (2010). Development of primer and probe sets for the detection of plant species in honey. Food Chemistry, 118(4), 979-986.

Madesis, P., Ganopoulos, I., Sakaridis, I., Argiriou, A., \& Tsaftaris, A. (2014). Advances of DNA-based methods for tracing the botanical origin of food products. Food Research International, 60, 163-172.

Pires, J., Estevinho, M. L., Feás, X., Cantalapiedra, J., \& Iglesias, A. (2009). Pollen spectrum and physico-chemical attributes of heather (Erica sp.) honeys of north Portugal. Journal of the Science of Food and Agriculture, 89(11), 1862-1870.

Prosser, S. W. J., \& Hebert, P. D. N. (2017). Rapid identification of the botanical and entomological sources of honey using DNA metabarcoding. Food Chemistry, 214, 183-191.

República Portuguesa. (2016). Programa apícola nacional 2017-2019. http://www. gpp.pt/images/Programas_e_Apoios/Apoios_de_Mercado/PAN/PAN2017-2019. pdf. (Accessed 15 June 2017).

Schnell, I. B., Fraser, M., Willerslev, E., \& Gilbert, M. T. P. (2010). Characterisation of insect and plant origins using DNA extracted from small volumes of bee honey. Arthropod-Plant Interactions, 4(2), 107-116.

Selvaraj, D., Sarma, R. K., \& Sathishkumar, R. (2008). Phylogenetic analysis of chloroplast matK gene from Zingiberaceae for plant DNA barcoding. Bioinformation, 3, 24-27.

Soares, S., Amaral, J. S., Oliveira, M. B. P. P., \& Mafra, I. (2015). Improving DNA isolation from honey for the botanical origin identification. Food Control, 48, 130-136.

Soares, S., Amaral, J. S., Oliveira, M. B. P. P., \& Mafra, I. (2017). A comprehensive review on the main honey authentication issues: Production and origin. Comprehensive Reviews in Food Science and Food Safety, 16, 1072-1100.

Valentini, A., Miquel, C., \& Taberlet, P. (2010). DNA barcoding for honey biodiversity. Diversity, 2(4), 610.

Villa, C., Costa, J., Meira, L., Oliveira, M. B. P. P., \& Mafra, I. (2016). Exploiting DNA mini-barcodes as molecular markers to authenticate saffron (Crocus sativus L.). Food Control, 65, 21-31.

Villa, C., Costa, J., Oliveira, M. B. P. P., \& Mafra, I. (2017). Novel quantitative real-time PCR approach to determine safflower (Carthamus tinctorius) adulteration in saffron (Crocus sativus). Food Chemistry, 229, 680-687.

Xanthopoulou, A., Ganopoulos, I., Kalivas, A., Osathanunkul, M., Chatzopoulou, P., Tsaftaris, A., et al. (2016). Multiplex HRM analysis as a tool for rapid molecular authentication of nine herbal teas. Food Control, 60, 113-116. 